\title{
Optimalisasi Promosi Kesehatan Rumah Sakit dalam Mewujudkan Gerakan Masyarakat Hidup Sehat Berkemajuan di Rumah Sakit Muhammadiyah
}

\author{
Emma Rachmawati ${ }^{1}$, Mochamad Iqbal Nurmansyah ${ }^{1,2}$, Betty Semara Laksmi ${ }^{3}$, \\ Yuyun Umniyatun ${ }^{1}$, Lia Kharisma Saraswati ${ }^{4}$ \\ ${ }^{1}$ Fakultas Ilmu-ilmu Kesehatan, Universitas Muhammadiyah Prof. Dr. Hamka, ${ }^{2}$ Fakultas \\ Ilmu-ilmu Kesehatan, Universitas Islam Negeri Syarif Hidayatullah, Jakarta., ${ }^{3}$ Fakultas \\ Kedokteran, Universitas Muhammadiyah Prof. Dr. Hamka, ${ }^{4}$ Majelis Pembina Kesehatan \\ Umum, Pimpinan Pusat Muhammadiyah \\ iqbanurmansyah@,uinjkt.ac.id
}

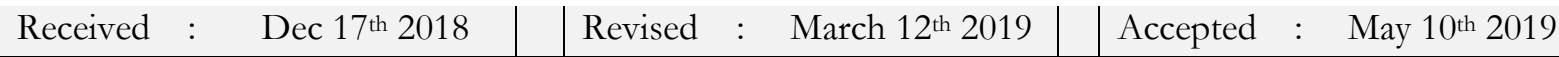

\begin{abstract}
Nowadays, Indonesia faces a problem with infectious and non-infectious diseases. To implement a collaborative health program, this assistance activity involved the community, the General Health Advisory Council PP Mubammadiyah, and Ministry of Health, Indonesia to implement the Healtby Life Movement. Mentoring activities took place from July to November 2018 by using partnership method. The partnership facilitates Health Volunteers to implement HPH outside of Hospital and develop health promotion media for the implementation of HPH. The tools for promotion are posters, leaflets, manual fans, and guidelines for measuring nutrition. This health promotion is the implementation form of Healthy Life Movement for the community. HPH programs have been carried out in various areas, they are 6 Mubammadiyab Hospitals in 4 provinces of Indonesia.
\end{abstract}

Keywords: Health Promotion, Collaborative Health Program, Healthy Life Movement

\section{Pendahuluan}

Indonesia saat ini mengalami triple burden diseases dimana terdapat ancaman kesehatan yakni: (1) belum selesainya masalah penyakit menular seperti Tuberculosis (TB), diare, malaria, (2) munculnya masalah kesehatan lama yang muncul kembali re-emerging atau new emerging diseases seperti HIV/AIDS, avian flu, dan (3) mulai meningkatnya penyakit tidak menular seperti hipertensi, kanker dan diabetes. ${ }^{1}$ Dengan permasalahan kesehatan tersebut maka pada tahun 2018 ini Kementerian Kesehatan RI berfokus pada pencapaian Universal Health Coverage melalui percepatan eliminasi TB, penurunan Stunting (Gagal Tumbuh/Kerdil) dan peningkatan cakupan serta pelayanan imunisasi. ${ }^{2}$

Ketiga permasalahan tersebut yang menjadi fokus pemerintah dan menjadi bagian dari

${ }^{1}$ Sarimawar Djaja, "Analisis Penyebab Kematian Dan Tantangan Yang Dihadapi Penduduk Lanjut Usia Di Indonesia Menurut Riset Kesehatan Dasar 2007," Buletin Penelitian Sistem Kesehatan 15, no. 4 (2012): 323-330.

${ }^{2}$ Kemenkes RI Direktorat Jenderal Pencegahan dan Pengendalian Penyakit, "Melalui Rakerkesnas 2018, Kemenkes Percepat Atasi Masalah Kesehatan Stunting, Tuberculosis Dan Imunisasi."

Volume 3, Number 1, Mei $2019 \mid 80$

Optimalisasi Promosi Kesehatan Rumah Sakit dalam Mewujudkan Gerakan Masyarakat Hidup Sehat Berkemajuan di Rumah Sakit Muhammadiyah

Emma Rachmawati, Muchamad Iqbal Nurmansyah, Betty Samara Laksmi, Yuyun Umniyatun, Lia Kharisma Saraswati 
prioritas pengawasan sampai tahun 2019. Untuk kasus TB, World Health Organization (WHO) menyebutkan bahwa di tahun 2016, Indonesia menempati posisi kedua dengan insiden TB tertinggi di dunia. ${ }^{3}$ Berdasarkan studi Global Burden of Disease, TB menjadi penyebab kematian ke dua di dunia. Angka terbaru Insidens TB di Indonesia adalah 321 per 100.000. ${ }^{4}$ Terkait stunting, terdapat sekitar 37\% atau sekitar hampir 9 juta anak balita di Indonesia mengalami stunting. Data Riskesdas 2018 menunjukkan bahwa proporsi status gizi sangat pendek dan pendek pada balita adalah 30,8\% dan pada baduta 29,9\% (Target RPJMN adalah 28\%). Secara global, Indonesia menempati posisi kelima dengan prevalensi stunting tertinggi di dunia. Dampak buruk bagi balita dengan stunting diantaranya adalah tingkat kecerdasan kurang maksimal, anak lebih rentan terhadap penyakit dan berisiko penurunan tingkat produktivitas di masa depan. ${ }^{5}$

Begitu juga dengan cakupan imunisasi, data Riskesdas 2013 menyebutkan hanya mencapai 59,2\%. Kondisi tersebut tidak sebagus pada setiap Provinsi di Indonesia dimana masih terdapat kesenjangan yang bervariasi pada cakupan imunisasi antar Provinsi di Indonesia. Data cakupan Universal Child Immunization (UCI) menyebutkan bahwa terdapat 292 kabupaten/kota (59,8\%) telah mencapai $80 \%$ cakupan imunisasi dasar lengkap pada bayi $12-23$ bulan, namun angka tersebut belum sesuai target RPJMN (Rencana Pembagunan Jangka Menengah Nasional) di bidang kesehatan tahun 2015 yaitu sebesar 75\%, ${ }^{6}$ dan tahun 2019 ini mencapai 57,9\% (target RPJMN 93\% pada tahun 2019). ${ }^{7}$

Pengentasan permasalahan tersebut di atas pada hakekatnya adalah upaya kesehatan yang harus dilaksanakan oleh semua komponen bangsa Indonesia. Konsep WHO tentang health in all policies mengamanatkan bahwa upaya kesehatan dilaksanakan secara multisektoral yang merujuk pada keterlibatan pemerintah dan keterlibatan di luar pemerintahan termasuk swasta, profesional, organisasi sosial kemasyarakatan yang dinamakan dengan multistakeholder. Salah satu bentuk upaya pelibatan multisektoral adalah melalui promosi Gerakan Masyarakat Hidup Sehat (GERMAS), yang dituangkan dalam bentuk INPRES RI (Instruksi Presiden Republik Indonesia) Nomor 1 Tahun 2017 tentang GERMAS. Peraturan tersebut salah satu diantaranya adalah mengatur berbagai peran pemangku kepentingan baik lembaga pemerintahan, swasta, lembaga sosial/organisasi kemasyarakatan (Ormas) melalui kegiatan kemitraan untuk mensukseskan pelaksanaan GERMAS.

${ }^{3}$ WHO World Health Organization, Global Tuberculosis Report (Switzerland, 2017).

${ }^{4}$ Badan Penelitian dan Pengembangan Kesehatan, Hasil Utama Riskesdas 2018 (Jakarta, 2018).

5 Tim Nasional Percepatan Penanggulangan Kemiskinan TNP2K, 100 Kabupaten/Kota Prioritas Untuk Intervensi Anak Kerdil (Stunting), Ringkasan, Pertama. (Jakarta Pusat, 2017).

${ }^{6}$ Kemenkes RI Pusat Data dan Informasi, InfoDatin-Imunisasi-2016 (Jakarta, 2016).

${ }^{7}$ Badan Penelitian dan Pengembangan Kesehatan, Hasil Utama Riskesdas 2018.

Volume 3, Number 1, Mei $2019 \mid 81$

Optimalisasi Promosi Kesehatan Rumah Sakit dalam Mewujudkan Gerakan Masyarakat Hidup Sehat Berkemajuan di Rumah Sakit Muhammadiyah 
Untuk tujuan tersebut, Direktorat Promosi Kesehatan dan Pemberdayaan Masyarakat Kemenkes RI kemudian melakukan kemitraan dengan berbagai ormas yang ada di Indonesia, termasuk ormas keagamaan. Sejak tahun 2011 Direktorat Promosi Kesehatan dan Pemberdayaan Masyarakat Kemenkes RI telah bermitra dengan PP (Pimpinan Pusat) Muhammadiyah cq MPKU (Majlis Pembina Kesehatan Umum) PP Muhammadiyah melalui program Promosi Kesehatan di Rumah Sakit (PKRS) di RSMA (RS Muhammadiyah 'Aisyiyah) yang berada di Yogyakarta, Makassar, DKI Jakarta, Bandung, Palangkaraya, Tegal, Bumiayu, Palembang, Sumatera Utara, Padang, Kendal Jateng, Sepanjang Jatim, dan Palangkaraya. Pemilihan PKRS ini berdasarkan data bahwa Muhammadiyah memiliki potensi berupa kepemilikan 105 RSMA di berbagai pelosok di Indonesia. ${ }^{8}$ Promosi Kesehatan Rumah Sakit (PKRS) sendiri bertujuan memberikan pelayanan medis dan perawatan dengan kualitas yang tinggi secara komprehensif melalui kegiatan Promkes kepada pasien, staf RS dan masyarakat sebagai bagian dari identitas dan praktik rutin RS. Artinya, RS mengintegrasikan upaya promosi dan pendidikan kesehatan, pencegahan penyakit dan pelayanan rehabilitasi dalam pelayanan kuratif. ${ }^{9}$

Pada tahun 2018, sesuai dengan tiga prioritas masalah kesehatan yang terjadi di tingkat nasional sebagaimana diuraikan di atas, MPKU PP Muhammadiyah melaksanakan kegiatan kemitraan bersama Direktorat Promosi Kesehatan dan Pemberdayaan Masyarakat Kementerian Kesehatan RI untuk melakukan kembali optimalisasi Gerakan Masyarakat Hidup Sehat (GERMAS) Berkemajuan, penurunan stunting dan eliminasi TB melalui program PKRS di enam Rumah Sakit Muhammadiyah yang tersebar di empat Provinsi yakni Jawa Timur, DKI Yogyakarta, Sulawesi Selatan dan Jawa Tengah. Penambahan tema "Berkemajuan" pada "GERMAS Berkemajuan" sesuai dengan tema gerakan Muhammadiyah yang ditetapkan di Muktamar Muhammadiyah ke-47 di Makassar tahun 2015, yang menjadi nilai, etos, spirit, dan cita-cita gerakan Muhammadiyah ke depan. ${ }^{10}$

\section{Metode}

Kegiatan pengabdian masyarakat dilakukan selama bulan Juli s/d November tahun 2018. Secara umum, tahapan kegiatan pengabdian masyarakat yang dilakukan tersaji pada Bagan 1. Adapun pemilihan wilayah dilakukan dengan melihat data-data pendukung yang terkait isu-isu

\footnotetext{
8 Majelis Pembina Kesehatan Umum PP Muhammadiyah, Panduan Dakwah Amal Usaha Kesehatan Muhammadiyah, Buku Pendamping, Cetakan 1. (Yogyakarta: Suara Muhammadiyah, 2017).

9 WHO, "Standards for Health Promotion in Hospitals" (2004): 1-16.

${ }^{10}$ Ahmad Fuad Fanani et al., Islam Berkemajuan Untuk Peradaban Dunia, ed. Alpha Amirrachman, Andar Nubowo, and Khoirudin Azaki, I. (Bandung: PT Mizan Pustaka, 2015).
} 


\section{ENGAGEMENT}

GurnalPengabdianKepadaMasyarakat

ISSN : 2579-8375 (Print)

ISSN : 2579-8391 (Online)
This work is licensed under a Creative Commons Attribution-ShareAlike 4.0 International License. CC BY SA

Penurunan Stunting, Eliminasi TBC dan Peningkatan Cakupan dan Pelayanan Imunisasi dan optimalisasi Germas. Lokasi kegiatan dilaksanakan di 6 Rumah sakit Muhammadiyah yang berada di 4 Provinsi. Lokasi detil kegiatan dapat dilihat pada Tabel 1 dan tahapan kegiatan dapat dilihat pada tabel 1 dan bagan 1 berikut ini:

Tabel 1.

Lokasi Pengabdian Masyarakat

\begin{tabular}{|l|l|l|}
\hline \multicolumn{1}{|c|}{ Fokus } & \multicolumn{1}{|c|}{ Provinsi } & \multicolumn{1}{c|}{ Nama RS } \\
\hline \multirow{2}{*}{$\begin{array}{l}\text { Optimalisasi } \\
\text { Germas }\end{array}$} & Jawa Timur & RS Muhammadiyah Sitti Khadijah Sidoarjo \\
\cline { 2 - 3 } & Sulawesi Selatan & RS Muhammadiyah Sitti Khadijah I Makassar \\
\hline Penurunan Stunting & Jawa Timur & RS Muhammadiyah Lamongan \\
\hline & Jawa Tengah & RS Muhamadiyah Sruweng Kebumen \\
\hline & Yogyakarta & RS Muhammadiyah Nanggulan Kulonprogo \\
\hline Eliminasi TB & Jawa Tengah & RS Muhammadiyah Karanganyar \\
\hline
\end{tabular}

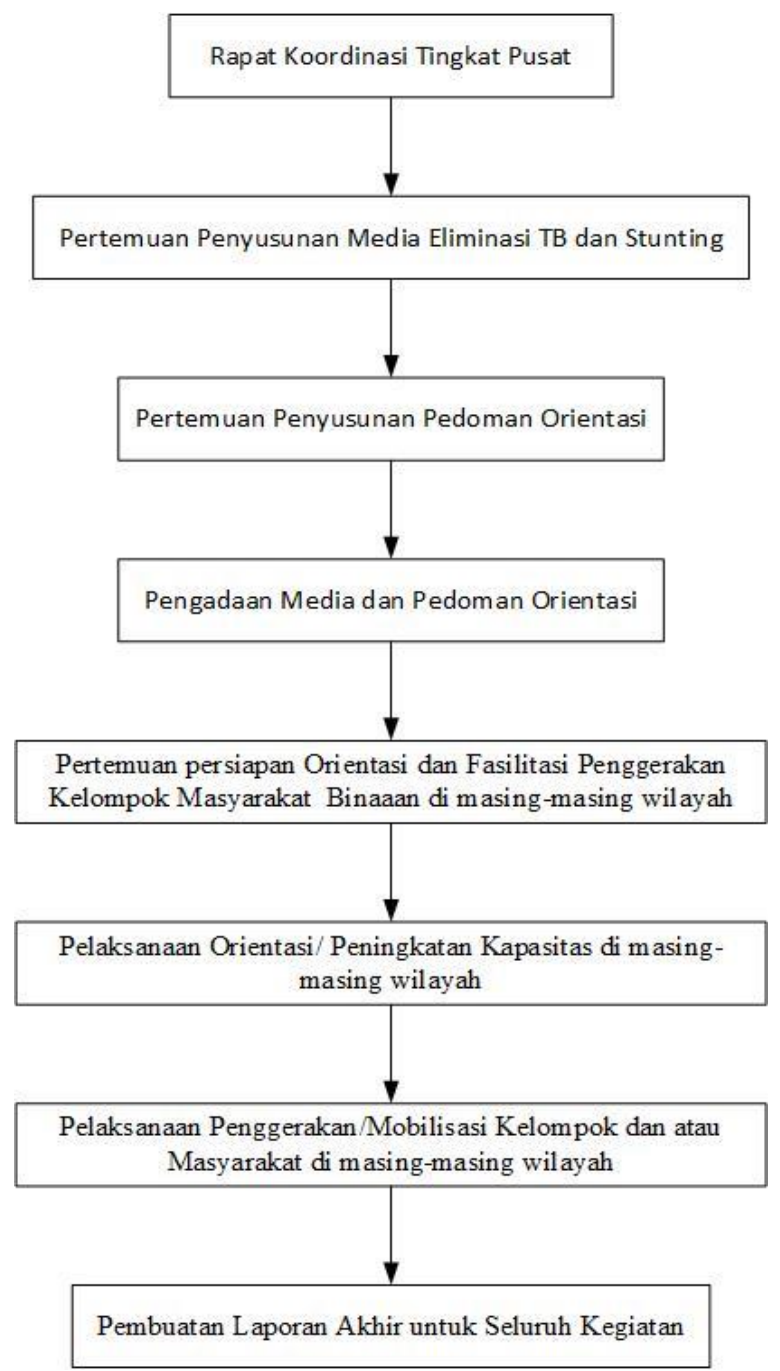

Bagan 1. Tahapan Kegiatan

Volume 3, Number 1, Mei 2019 | 83

Optimalisasi Promosi Kesehatan Rumah Sakit dalam Mewujudkan Gerakan Masyarakat Hidup Sehat Berkemajuan di Rumah Sakit Muhammadiyah 
Kegiatan rapat koordinasi tingkat pusat dilaksanakan untuk menyamakan persepsi program, merencanakan lebih rinci kegiatan, menyusun rencana anggaran belanja dan koordinasi tingkat pusat dan daerah. Selanjutnya adalah menyusun media promosi kesehatan sesuai dengan tema kegiatan. Tahapan selanjutnya adalah menyusun dan menyempurnakan Pedoman dan media promosi untuk pelaksanaan penggerakan masyarakat terhadap optimalisasi Germas Berkemajuan, peran serta Ormas Muhammadiyah dalam Pencegahan Stunting, dan Eliminasi TBC.

Sebelum penggerakan pengabdian masyarakat, dilakukan koordinasi teknis antara pimpinan MPKU Pusat dan Wilayah, Daerah, Cabang, Ranting, Dinas Kesehatan Kab/Kota, Direktur RSM, tim PKRS, Puskesmas, dan Kader Kesehatan (Ortom Muhammadiyah) untuk Orientasi dan Fasilitasi Penggerakan Kelompok Masyarakat Binaan. Dalam pelaksanaan orientasi dilakukan pelatihan kader. Pelatihan kader bertujuan untuk meningkatkan pengetahuan fasilitator/kader/pembina teknis Muhammadiyah tentang Germas Berkemajuan, Pencegahan Stunting, Eliminasi TBC dan Cakupan dan Pelayanan Imunisasi dan meningkatkan kemampuan fasilitator/kader/pembina teknis Muhammadiyah untuk melakukan penggerakan masyarakat dalam Germas Berkemajuan. Pendidikan masyarakat dilakukan melalui kegiatan Pelaksanaan Penggerakan/Mobilisasi Kelompok dan atau Masyarakat. Tujuan dari kegiatan ini adalah (1) melaksanakan penggerakan masyarakat tentang Germas Berkemajuan, penurunan stunting, eliminasi TBC; (2) membentuk kelompok masyarakat untuk optimalisasi Germas Berkemajuan dan Penggerakan Ormas Muhammadiyah dalam Penurunan Stunting, Eliminasi TBC, Cakupan dan Pelayanan Imunisasi; dan (3) terlaksananya PKRS RSM di luar gedung.

\section{Hasil dan Diskusi}

\section{Pengembangan Media Promosi Kesehatan}

Tahap pertama pelaksanaan kegiatan adalah Tahap Persiapan berupa Koordinasi Tim Pelaksana Pusat yaitu pertemuan antara Direktorat Promosi Kesehatan dan Pemberdayaan Masyarakat Kemenkes RI dan Majelis Pembina Kesejahteraan Umat (MPKU) yang dilaksanakan sebanyak 2 (dua) kali pada hari Selasa 31 Juli 2018 dan Jumat 10 Agustus 2018. Dalam Pertemuan koordinasi ini tercapai kesamaan pemahaman dan kesepakatan dalam pelaksanaan program Germas dan tersusun rencana kegitan (PoA/Plan of Action) untuk tahun 2018. Kegiatan dilanjutkan dengan penyusunan dan pembuatan media konten buku orientasi Gerakan masyarakat (Germas), TBC, dan Stunting, Poster Germas, TBC, dan Stunting, Leaflet Germas, TBC dan Stunting, Cakram Stunting dan Kalender TBC yang bercirikan Al-Islam ke-Muhammadiyahan (Lihat Gambar 1. selama kurang lebih 2 bulan di bulan Agustus - September 2018 dengan berkoordinasi 


\section{ENGAGEMENT}

JurnalPengabdian KepadaMasyarakat

ISSN : 2579-8375 (Print)

ISSN : 2579-8391 (Online)

dengan Direktorat Promosi Kesehatan dan Pemberdayaan Masyarakat Kemenkes RI.

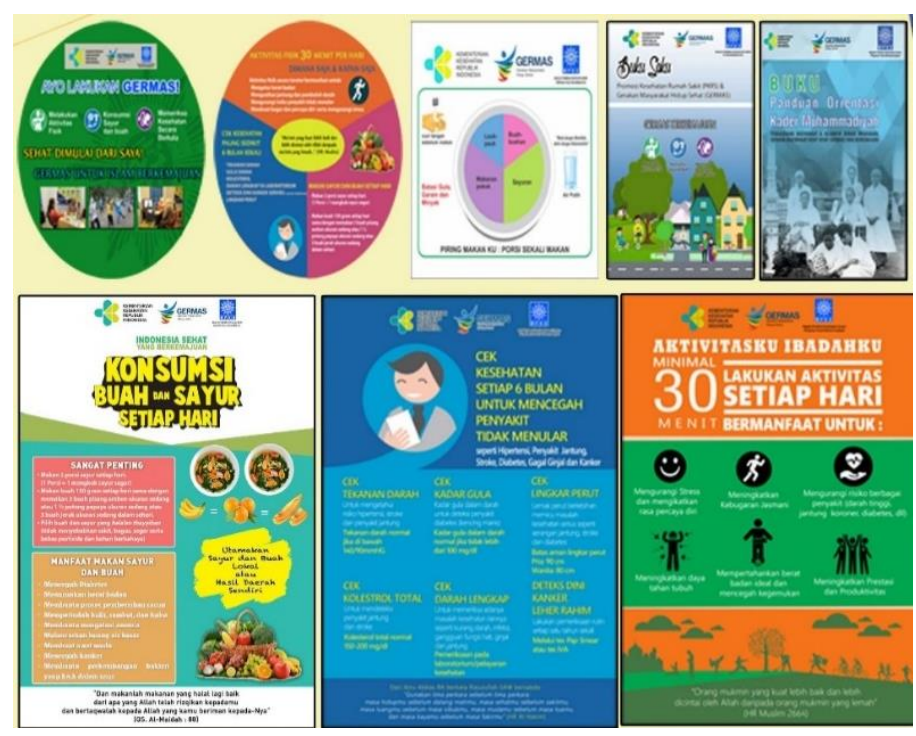

Gambar 1. Media Promosi Kesehatan Germas Berkemajuan MPKU PP Muhammadiyah Tahun 2018

\section{Orientasi Kader Kesehatan}

Kegiatan orientasi kader kesehatan dihadiri 30 peserta di masing-masing RS yang terdiri dari Tim PKRS, Dinas kesehatan Propinsi/Kabupaten/Kota, Puskesmas, Tokoh Agama/Masyarakat dari Pimpinan Muhammadiyah Daerah/Cabang/Ranting, Pimpinan Aisyiyah Daerah/Cabang/Ranting, Kader Kesehatan, dan tokoh masyarakat desa binaan. Di sini terlihat kontribusi nyata Dinas KesehatanKab/Kota, Kader Desa Binaan RS, Pimpinan Wilayah s/d Ranting Muhammadiyah/Aisyiyah.

Orientasi ini menggunakan metode pembelajaran orang dewasa, dengan melakukan ceramah singkat dengan komunikasi 2 arah, tanya jawab untuk hal-hal yang baru, curah pendapat untuk penjajakan pengalaman, serta penugasan. Adapun proses pembelajaran pada orientasi dilaksanakan melalui beberapa tahapan yaitu:

1. Dinamisasi dan penggalian harapan peserta serta membangun komitmen belajar di antara peserta;

2. Penyiapan peserta sebagai individu atau kelompok yang mempunyai pengaruh pada penggerakan masyarakat di sekitarnya untuk menciptakan iklim yang kondusif dalam melaksanakan tugas;

3. Penjajakan awal peserta dengan memberikan pra tes berupa 25 pertanyaan pilihan ganda;

Volume 3, Number 1, Mei $2019 \mid 85$

Optimalisasi Promosi Kesehatan Rumah Sakit dalam Mewujudkan Gerakan Masyarakat Hidup Sehat Berkemajuan di Rumah Sakit Muhammadiyah

Emma Rachmawati, Muchamad Iqbal Nurmansyah, Betty Samara Laksmi, Yuyun Umniyatun, Lia Kharisma Saraswati 
4. Pembahasan materi kelas, peserta dilibatkan secara aktif berupa tanya jawab dan diskusi kelompok;

5. Praktik simulasi di kelas;

6. Penugasan membuat Rencana Tindak Lanjut (RTL) per-desa binaan;

7. Penjajakan akhir peserta dengan memberikan post tes berupa 25 pertanyaan pilihan ganda.

Tabel 2.

Kelompok Penggerakan Masyarakat

\begin{tabular}{|c|c|c|}
\hline Nama Rumah Sakit & Kelompok di RS & Kelompok di Desa \\
\hline $\begin{array}{l}\text { RS. Muhammadiyah } \\
\text { Lamongan }\end{array}$ & $\begin{array}{l}\text { 1. Kelompok Peduli } \\
\text { Stunting } \\
\text { 2. Kelompok Balita }\end{array}$ & Kelompok Posbindu \\
\hline $\begin{array}{l}\text { RS. Siti Khodijah } \\
\text { Sepanjang, Sidoarjo }\end{array}$ & $\begin{array}{l}\text { 1. Kelompok aktivitas } \\
\text { fisik } \\
\text { 2. Kelompok cek } \\
\text { kesehatan }\end{array}$ & $\begin{array}{l}\text { 1. Kelompok deteksi dini PTM } \\
\text { 2. Kelompok penggerakan makan } \\
\text { sayur dan buah } \\
\text { 3. Kelompok aktivitas fisik } \\
\text { 4. Kelompok Sukseskan ASI } \\
\text { Eksklusif } \\
\text { 5. Kelompok pencegahan merokok }\end{array}$ \\
\hline $\begin{array}{l}\text { RSU PKU } \\
\text { Muhammadiyah } \\
\text { Nanggulan, Kulon Progo }\end{array}$ & $\begin{array}{l}\text { 1. Kelompok Peduli } \\
\text { Stunting } \\
\text { 2. Kelompok Balita }\end{array}$ & Kelompok Posbindu \\
\hline $\begin{array}{l}\text { RS PKU Muhammadiyah } \\
\text { Karanganyar Surakarta }\end{array}$ & Kelompok Peduli TBC & Kelompok Posbindu \\
\hline $\begin{array}{l}\text { RS PKU Muhammadiyah } \\
\text { Sruweng, Kebumen }\end{array}$ & $\begin{array}{l}\text { 1. Kelompok Peduli } \\
\text { Stunting } \\
\text { 2. Kelompok Balita }\end{array}$ & Kelompok Posbindu \\
\hline $\begin{array}{l}\text { RSIA Muhammadiyah Siti } \\
\text { Khadijah Makassar }\end{array}$ & $\begin{array}{l}\text { 1. Kelompok aktivitas } \\
\text { fisik } \\
\text { 2. Kelompok cek } \\
\text { kesehatan }\end{array}$ & $\begin{array}{l}\text { 1. Kelompok deteksi dini PTM } \\
\text { 2. Kelompok penggerakan makan } \\
\text { sayur dan buah } \\
\text { 3. Kelompok aktivitas fisik } \\
\text { 4. Kelompok Sukseskan ASI } \\
\text { Eksklusif } \\
\text { 5. Kelompok pencegahan merokok }\end{array}$ \\
\hline
\end{tabular}

Pokok-pokok bahasan dalam materi yang disajikan meliputi:

1. Gambaran Implementasi dan Penyajian Germas Aktivitas Fisik, Makan sayur dan buah, deteksi dini Penyakit Menular (TBC) maupun Penyakit Tidak Menular (Stunting);

2. Tugas dan Tanggungjawab Kader di tingkat Wilayah, Daerah, Cabang dan Ranting;

3. Simulasi Pemberdayaan dan Penggerakan Masyarakat; 


\section{ENGAGEMENT}

JurnalPengabdian KepadaMasyarakat

ISSN : 2579-8375 (Print)

ISSN : 2579-8391 (Online)

4. Rencana PKRS di RS dan bagaimana langkah-langkah membentuk Kelompok Penggerakan Masyarakat.

Setelah kegiatan Orientasi di 6 Rumah Sakit Muhammadiyah/Aisyiyah terlaksana dengan baik dan dan hasil kegiatan dapat dirinci sebagai berikut:

1. Meningkatkan pengetahuan fasilitator/kader/pembina teknis Muhammadiyah tentang Germas/Eliminasi TB/Penurunan Stunting terlihat dari peningkatan nilai post test dibandingkan dengan post tes;

2. Meningkatkan kemampuan fasilitator/kader/pembina teknis Muhammadiyah untuk melakukan penggerakan masyarakat dalam Germas/Eliminasi TB/Penurunan Stunting terlihat saat praktik simulasi;

3. Terbentuk Kelompok Penggerakan Masyarakat yang terdiri dari Kelompok Penggerakan Masyarakat di Desa Binaan danKelompok Penggerakan Masyarakat di RS (Lihat tabel 2).

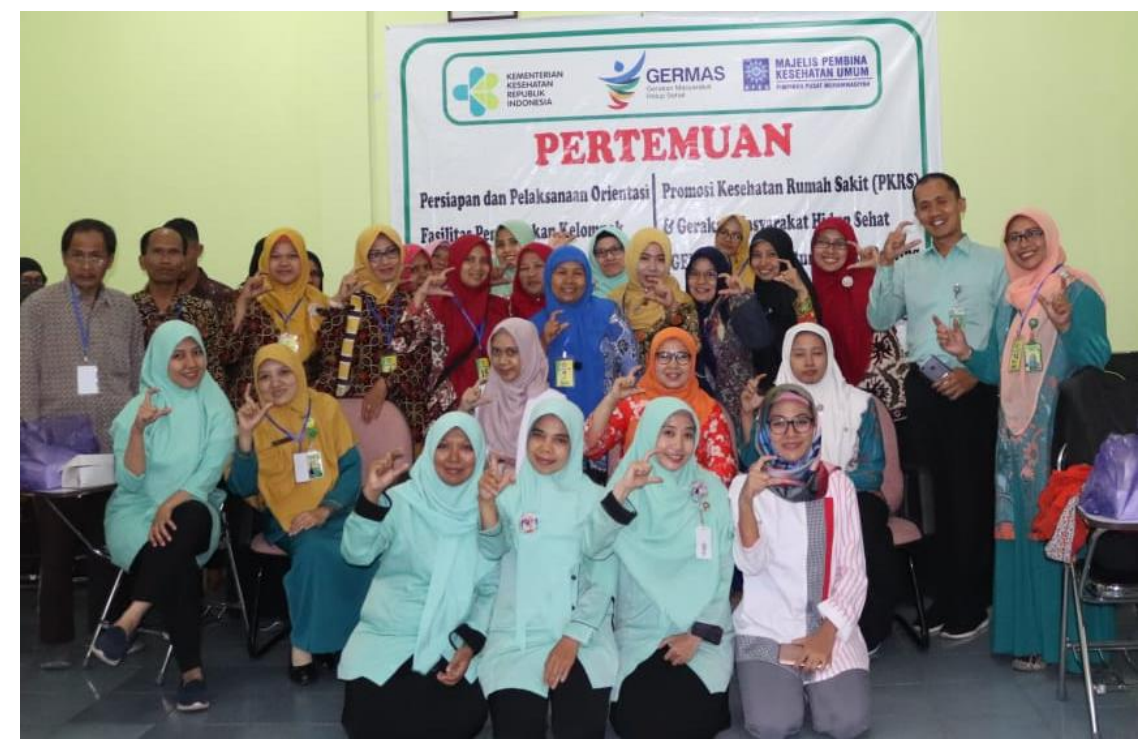

\section{Gambar 2. Orientasi Kader Kesehatan dan Tim PKRS Rumah Sakit di Rumah Sakit Muhammadiyah Sruweng}

\section{Penggerakan Kelompok Masyarakat}

Kegiatan puncak berupa Penggerakan Masyarakat dengan berbagai kegiatan antara lain sosialisasi program Germas/Eliminasi TB/Penurunan Stunting, Fasilitasi masyarakat dalam Germas/Eliminasi TB/Penurunan Stunting, penggerakkan kelompok masyarakat dari unsur kader, desa binaan untuk ikut serta dalam kegiatan Gerakan Masyarakat Sehat. Pelaksanaa kegiatan secara terinci dapat dilihat pada tabel 3.

Volume 3, Number 1, Mei $2019 \mid 87$

Optimalisasi Promosi Kesehatan Rumah Sakit dalam Mewujudkan Gerakan Masyarakat Hidup Sehat Berkemajuan di Rumah Sakit Muhammadiyah 


\title{
Tabel 3.
}

\section{Kegiatan Penggerakan Masyarakat}
RS. Muhammadiyah Lamongan (100 peserta)
1. Penyuluhan dalam kelompok kelas ibu hamil dan Balita sejumlah 40 orang
2. Seminar Parenting tentang Pola asuh dalam mencegah stunting
3. Kunjungan dokter spesialis Anak RSM untuk pencegahan stunting di Posyandu.
4. Melakukan kegiatan Masak Menu atau Lomba masak bahan lokal dan Gizi Seimbang.
5. Pembinaan posyandu yang tidak sktif menjadi aktif

\author{
RS. Sitti Khodijah Sepanjang, Sidoarjo (132 peserta) \\ 1. Jalan sehat bersama seluruh peserta dipimpin oleh Direktur RS \\ 2. Cek kesehatan oleh Petugas Kesehatan Rumah Sakit \\ 3. Bazar sayur dan buah oleh pedagang buah dan sayur lokal \\ 4. Stand konsultasi gizi oleh petugas kesehatan rumah sakit \\ 5. Lomba senam Diabetes \\ 6. Lomba kreasi makanan sehat dimana setiap peserta yang terdiri dalam grup melakukan \\ penyusunan makanan yang telah disediakan panitia sesuai dengan kriteria posi makanan \\ sehat
}

\section{RSU PKU Muhammadiyah Nanggulan, Kulon Progo (80 peserta)}

1. Penyuluhan dalam kelompok kelas ibu hamil dan Balita

2. Seminar Parenting tentang Pola asuh dalam mencegah stunting.

3. Kunjungan dokter spesialis Anak RSM untuk pencegahan stunting di Posyandu Wilayah Kabupaten Nanggulan bekerjasama dengan Puskesmas.

4. Melakukan kegiatan Masak Menu atau Lomba masak bahan lokal dan Gizi Seimbang.

5. Adanya pembinaan posyandu yang tidak aktif menjadi aktif

\section{RS PKU Muhammadiyah Karanganyar Surakarta (70 peserta) \\ 1. Seminar tentang Program Toss TBC \\ 2. Pendandatanganan Komitmen Bersama}

\footnotetext{
RS PKU Muhammadiyah Sruweng, Kebumen (80 peserta)

1. Penyuluhan dalam kelompok kelas ibu hamil dan Balita

2. Seminar Kesehatan Ibu dan Anaka tentang Pola asuh dalam mencegah stunting.

3. Kunjungan dokter spesialis Anak RSM untuk pencegahan stunting di Posyandu Kabupaten Kebumen bekerjasama dengan Puskesmas.

4. Melakukan kegiatan Masak Menu atau Lomba masak bahan lokal dan Gizi Seimbang,

5. Adanya pembinaan posyandu yang tidakaktif menjadi aktif
}

Kegiatan yang dilakukan di tiap rumah sakit beragam yakni mulai dari seminar dalam rangka peningkatan pengetahuan terkait dengan germas, pencegahan stunting, jelan sehat, cek kesehatan oleh petugas rumah sakit, konsultasi gizi, bazar sayur dan buah murah serta berbagai kegiatan menarik lainnya. Kelompok masyarakat yang digerakkan juga berbeda-beda dimana ada 


\section{ENGAGEMENT}

JurnalPengabdian KepadaMasyarakat

ISSN : 2579-8375 (Print)

ISSN : 2579-8391 (Online)

yang menyasar ibu hamil dan menyusui, pasien dan keluarga TB serta masyarakat umum dimana hal tersebut didasarkan pada pokok permasalahan di masing-masing rumah sakit.

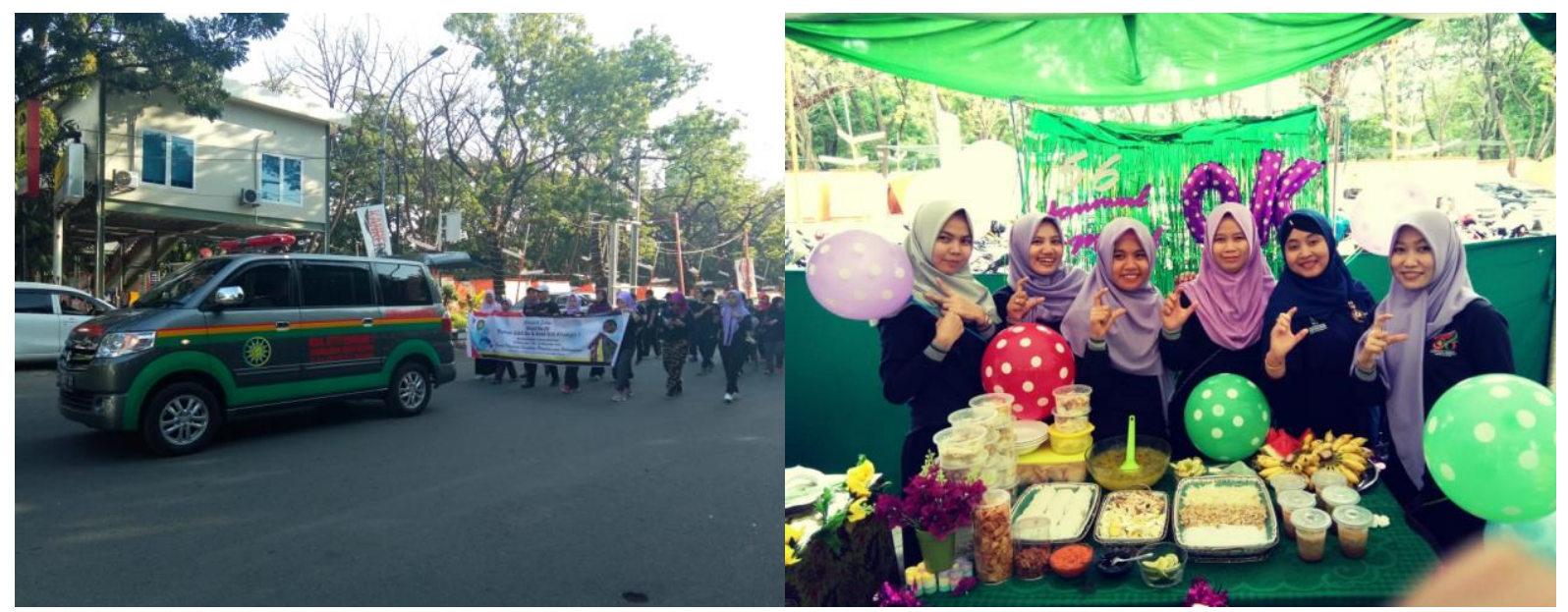

Gambar 3. Penggerakan Masyarakat (Jalan santai dan Bazar Makanan Sehat) di RS Sitti Khadijah I Makassar

Pada intinya, penggerakan masyarakat dilakukan dengan prinsip paradigma sehat dimana masyarakat tidak hanya menjadi objek pembangunan kesehatan namun juga menjadikannya pelaku pembangunan kesehatan. ${ }^{11}$ Dalam kegiatan penggerakan masyarakat juga terjadi adanya pelibatan kader kesehatan yang bersumber dari masyarakat. Pelibatan kader kesehatan dalam pengabdian masyarakat ini mampu berperan aktif dan menjadi pendorong, motivator dan penyuluh masyarakat. Selain itu, Kader kesehatan ini juga menjadi jembatan antara petugas/ahli kesehatan dengan masyarakat serta membantu masyarakat dalam mengidentifikasi dan menghadapi/menjawab kebutuhan kesehatan mereka sendiri. ${ }^{12}$

\section{Kesimpulan}

Kegiatan kemitraan antara Organisasi Masyarakat dan Pemerintah cq Direktorat Jenderal Promosi Kesehatan dan Pemberdayaan Masyarakat dalam penggerakan masyarakat untuk mewujudkan masyarakat hidup sehat menjadi salah satu upaya strategis yang perlu terus dilanjutkan agar kampanye gerakan hidup sehat kepada masyarakat dapat terus berlanjut secara lebih masif dan sistemis. Selain itu, melalui kegiatan kemitraan ini, masyarakat tidak hanya menjadi objek dalam gerakan kesehatan namun juga menjadikan mereka sebagai subjek dalam melaksanakan paradigma

\footnotetext{
${ }^{11}$ Febri Endra Budi Setyawan, "PARADIGMA SEHAT," Saintika Medika (2018).

${ }^{12}$ Dyah Wahyuningsih Widyo Subagyo, Mukhadiono, "Peran Kader Dalam Memotivasi Ibu Balita Berkunjung Ke Posyandu," Jurnal Keperawatan Soedirman (The Soedirman Journal of Nursing), Volume 10, No.3, November 2015 (2015).
}

Volume 3, Number 1, Mei $2019 \mid 89$

Optimalisasi Promosi Kesehatan Rumah Sakit dalam Mewujudkan Gerakan Masyarakat Hidup Sehat Berkemajuan di Rumah Sakit Muhammadiyah 
sehat sehingga masyarakat dapat lebih sadar dan dapat hidup sehat secara mandiri.

Kegiatan kemitraan antara Ormas Muhammadiyah dan Kementerian Kesehatan dalam kampanye Germas perlu dijaga keberlajutannya/sustainabilitasnya dengan upaya yang lebih inovatif dan luas dimana tidak hanya melibatkan rumah sakit dengan upaya promosi kesehatan rumah sakit namun juga dapat melibatkan amal usaha Muhammadiyah lainnya seperti sekolah, pondok pesantren serta perguruan tinggi Muhammadiyah. Selain itu, komitmen daripada pimpinan amal usaha Muhammadiyah dan pimpinan MPKU (Majlis Pembina Kesehatan Umum) PP Muhammadiyah di semua tingkatan (Pusat, Wilayah, Daerah, Cabang, dan Ranting) yang dilibatkan dalam kegiatan pengabdian masyarakat ini, untuk terus bisa melanjutkan kegiatan meskipun tidak ada lagi pembinaan secara teknis menjadi salah satu kunci untuk bisa menjaga sustainabilitas kegiatan di kalangan masyarakat.

\section{Daftar Referensi}

Badan Penelitian dan Pengembangan Kesehatan. Hasil Utama Riskesdas 2018. Jakarta, 2018.

Budi Setyawan, Febri Endra. "Paradigma Sehat.” Saintika Medika (2018).

Direktorat Jenderal Pencegahan dan Pengendalian Penyakit, Kemenkes RI. "Melalui Rakerkesnas 2018, Kemenkes Percepat Atasi Masalah Kesehatan Stunting, Tuberculosis Dan Imunisasi."

Djaja, Sarimawar. "Analisis Penyebab Kematian Dan Tantangan Yang Dihadapi Penduduk Lanjut Usia Di Indonesia Menurut Riset Kesehatan Dasar 2007.” Buletin Penelitian Sistem Kesehatan 15, no. 4 (2012): 323-330.

Fanani, Ahmad Fuad, Ahmad Najib Burhani, Amich Alhumami, Alpha Amirrachman, Azaki Khoirudin, Biyanto, Din Wahid, et al. Islam Berkemajuan Untuk Peradaban Dunia. Edited by Alpha Amirrachman, Andar Nubowo, and Khoirudin Azaki. I. Bandung: PT Mizan Pustaka, 2015.

Muhammadiyah, Majelis Pembina Kesehatan Umum PP. Panduan Dakwah Amal Usaha Kesehatan Muhammadiyah, Buku Pendamping. Cetakan 1. Yogyakarta: Suara Muhammadiyah, 2017.

Pusat Data dan Informasi, Kemenkes RI. InfoDatin-Imunisasi-2016. Jakarta, 2016.

TNP2K, Tim Nasional Percepatan Penanggulangan Kemiskinan. 100 Kabupaten/Kota Prioritas Untuk. Intervensi Anak Kerdil (Stunting), Ringkasan. Pertama. Jakarta Pusat, 2017.

WHO. "Standards for Health Promotion in Hospitals" (2004): 1-16. 


\section{ENGAGEMENT}

GurnalPengabdianKepadaMasyarakat

ISSN : 2579-8375 (Print)

ISSN : 2579-8391 (Online)
This work is licensed under a Creative Commons Attribution-ShareAlike 4.0 International License. CC BY SA

Widyo Subagyo, Mukhadiono, Dyah Wahyuningsih. "Peran Kader Dalam Memotivasi Ibu Balita Berkunjung Ke Posyandu." Jurnal Keperawatan Soedirman (The Soedirman Journal of Nursing), Volume 10, No.3, November 2015 (2015).

World Health Organization, WHO. Global Tuberculosis Report. Switzerland, 2017.

Volume 3, Number 1, Mei 2019|91

Optimalisasi Promosi Kesehatan Rumah Sakit dalam Mewujudkan Gerakan Masyarakat Hidup Sehat Berkemajuan di Rumah Sakit Muhammadiyah 